Matgorzata Stowik ${ }^{*}$

Słupsk

\title{
Grupy rówieśnicze a kryzysy religijne współczesnej młodzieży
}

W jaki sposób poszczególne grupy rówieśnicze wpływają na rozwój religijny młodzieży, a tym samym na występowanie i kształtowanie kryzysów religijnych? Czy zawsze jest to wpływ wyraźny, bezpośredni, czy pozostaje raczej utajony, może wręcz nikły? Od czego to zależy? I wreszcie, jakie ma to znaczenie dla pedagoga chrześcijańskiego, czy dla duszpasterzy? W niniejszym artykule spróbujemy odpowiedzieć na te pytania. Przede wszystkim odkryjemy i scharakteryzujemy te cechy, elementy funkcjonowania różnych grup rówieśniczych, które wpływają na wyodrębnianie się lub na sposób przeżywania kryzysów religijnych.

Zanim jednak zajmiemy się specyfiką kryzysów religijnych przeżywanych w poszczególnych grupach rówieśniczych, przypomnijmy, na czym polega wyjątkowe znaczenie tych grup i jakie są prawidłowości rozwoju religijnego w okresie dorastania.

\section{Grupy rówieśnicze w okresie dorastania}

Rodzina - szkoła - rówieśnicy - to podstawowe środowiska, w których młody człowiek spędza swój czas, w których toczy się jego codzienność, życie. Spośród tych środowisk rodzice, nauczyciele, wychowawcy tworzą świat dorosłych, zaś w opozycji do tego świata stoi młodzieżowa grupa rówieśnicza ${ }^{1}$.

\footnotetext{
* Dr Małgorzata Słowik - adiunkt w Zakładzie Pedagogiki Społecznej Akademii Pomorskiej w Słupsku.

${ }^{1}$ Grupy rówieśnicze są swoistymi zbiorowościami społecznymi, których wspólną cechą (wyróżnianą przez zewnętrznego obserwatora, bez względu na to, czy uczestnicy zbiorowości sobie tę cechę uświadamiaja, czy nie) jest ta sama kategoria wieku. Cz. Czapów, Grupy rówieśnicze, w: En-
} 
Przynależność do grupy rówieśniczej warunkuje dobre samopoczucie młodego człowieka, umożliwia mu przeżywanie własnej niezależności od rodziców, jest oparciem w trudnych życiowych chwilach, źródłem zrozumienia i emocjonalnego wsparcia. W grupie rówieśniczej młody człowiek znajduje nową, określoną pozycję społeczną dla siebie, nowy punkt odniesienia wobec reszty społeczeństwa. Rośnie znaczenie aprobaty, uznania ze strony rówieśników, co powoduje nasilanie się konformistycznych zachowań w grupie. Im bardziej jednostka utożsamia się z grupa rówieśników, im bardziej zależy jej na grupowej akceptacji, tym bardziej skłonna jest dostosować się do wymagań grupy. Na skutek tego przejmuje wartości i wzory zachowań charakteryzujące grupę, do której należy i z którą chce się identyfikować. Proces takiej asymilacji, interioryzacji ma na ogół nieuświadomiony charakter. Dążenie do przyswojenia i reprezentowania wartości i wzorców grupowych jest dla młodego człowieka naturalne i oczywiste.

Grupy rówieśnicze stanowią więc silny, rzeczywisty układ odniesienia normatywnego i czynnik kontroli społecznej (jednostki, które nie przestrzegają zasad i norm w nich przyjętych, są z nich wykluczane) $)^{2}$. Tym samym grupy rówieśnicze pełnią istotną rolę $\mathrm{w}$ wychowaniu dorastającego człowieka (mimo że ich wychowawcze oddziaływania są w większości nieświadome, niezamierzone, pozbawione stricte wychowawczych celów). W okresie dorastania grupy rówieśnicze wręcz przejmują (oczywiście nie całkowicie) funkcje wychowawcze, socjalizacyjne, które były dotychczas, to znaczy w okresie dzieciństwa, realizowane w rodzinie. Stymulują, podobnie jak rodzina, rozwój osobowości młodego człowieka, rozwijają jego kompetencje społeczne, formułują i egzekwują określone wzory zachowań.

Tym samym mogą mieć wpływ na rozwój jego religijności³. Zanim jednak odkryjemy na czym ten wpływ polega, warto przypomnieć główne cechy, kierunki przemian religijności w okresie dorastania ${ }^{4}$.

\section{Religijność (kryzysy religijne) w okresie dorastania}

Kształtująca się w okresie dorastania nowa umiejętność abstrakcyjnego, formalnego myślenia ${ }^{5}$ pozwala dorastającym osobom zdystansować się wobec otoczenia

cyklopedia pedagogiczna, red. W. Pomykało, Warszawa 1993, s. 220. Cechy, cele różnych grup społecznych zostały opisane między innymi przez: J. Szczepański, Elementarne pojęcia socjologii, Warszawa 1970, s. 245-248; S. Mika, Wstę do psychologii społecznej, Warszawa 1972, s. 187-191.

${ }^{2}$ B. Misztal, Grupy rówieśnicze młodzieży, Wrocław 1974, s. 66, 77.

${ }^{3}$ Religijność to taki sposób przeżywania przez osobę swego istnienia, który związany jest z określoną dziedziną transcendencji (Bogiem, wartościami i prawdami religijnymi). Wyraża się w postawie wobec wszystkich elementów religii, co wpływa na określone zachowania religijne i pozareligijne osoby. Por. E. Wysocka, Religijność a tolerancja. Obszary zależności, Kraków 2000, s. 28.

${ }^{4}$ Choć religijność każdego człowieka zależy od jego indywidualnych predyspozycji i doświadczeń, i w znacznej mierze kształtuje się pod wpływem środowiska, to w jej rozwoju można wyróżnić pewne etapy - właściwe etapom rozwoju ogólnego.

${ }^{5}$ W. Prężyna, Ksztaltowanie się życia religijnego w świetle psychologii rozwojowej, Znak 210 (1971)12, s. 1574. 
i wewnętrznie przewartościować to, co w dzieciństwie biernie stamtąd przejmowały (za sprawą mechanizmu naśladownictwa). Dlatego czynności, które dotychczas wykonywały z racji nakazu rodziców, teraz odrzucają albo wykonują pod wpływem własnych przekonań. Zasłyszane informacje o świecie i religii nieustannie konfrontują ze swoim postrzeganiem i opiniami. Odkrywają też w sobie zdolność introspekcji, obserwacji swoich myśli, uczuć, dążeń oraz pragnienie uwolnienia się od jakiejkolwiek krępującej opieki i poczucia zależności (czasem źródłem poczucia zależności może być błędnie postrzegana religia). Okres dorastania nie zawsze jednak pozostaje tylko czasem odrzucenia wierzeń i zachowań z dzieciństwa. Może być to również czas „religijnego przebudzenia”, otwarcia się na nowe horyzonty wiary ${ }^{6}$.

W swych upartych niekiedy dążeniach do zrozumienia siebie, otaczającego świata i transcendencji oraz odkrywania sensu życia młodzież napotyka wiele trudności. W związku z tym przeżywa wiele rozczarowań, szczególnie, gdy zdaje się tylko na własne siły?

Wśród religijnych wątpliwości, odczuwanych przez młodych ludzi wyodrębnia się wątpliwości: intelektualne (nieuznawanie pewnych prawd religijnych za dogmaty), naukowe (gdy naukowo uzasadnione fakty wydają się niemożliwe do pogodzenia z prawdami wiary), konfliktowe (wynikające z dostrzegania kontrastu między budzącym poczucie winy zachowaniem a przekonaniami religijnymi), ewolucyjne (będące konsekwencją przekraczania poprzedniego etapu w rozwoju religijnym), prowadzące do frustracji (spowodowane rozczarowaniem dorastającej osoby, że religia nie zaspakaja jej potrzeb, wymagań), wynikające z nieufności (będące skutkiem pustki uczuciowej) ${ }^{8}$.

W prawidłowo postępującym rozwoju religijność powinna zmierzać do osiągnięcia autonomii ${ }^{9}$ (okres kształtowania się religijności autonomicznej przypada na 12-17 rok życia) i autentyczności ${ }^{10}$ (okres kształtowania się religijności autentycznej przypada na 18-25 rok życia). Autonomia i autentyczność to nie tylko pożądane cechy religijności młodzieży. Są to zarazem cechy religijności dojrzałej ${ }^{11}$. Dokładniej: autonomia uznawana jest za cechę dojrzałej motywacji religijnej. Motywy religijne powinny bowiem mieć charakter autonomiczny i niezależny, a nie tylko instrumentalny. Oznacza to, że wartości religijne mają być cenione i poszukiwane dla nich

${ }^{6}$ J. Bagrowicz, Edukacja religijna współczesnej młodzieży. Źródła i cele, Torun 2000, s. 93.

${ }^{7}$ D. Elkind, Geneza religii u dziecka, w: Psychologia religii. Wybór tekstów, red. H. Grzymała-Moszczyńska, Kraków 1984, cz. 1, s. 118-119.

${ }^{8}$ P. Jonata, Psychoterapia a problemy życia religijnego, Kraków 1993, s. 131.

${ }^{9}$ Autonomia polega na zrozumieniu i akceptacji zinternalizowanych w wyniku wychowania wartości oraz na podporządkowaniu własnego działania tym wartościom.

${ }^{10}$ Autentyczność zaczyna kształtować się w końcowej fazie okresu dorastania oraz jest zaprzeczeniem konformistycznego naśladownictwa i dostosowywania się do panujących w otoczeniu modeli myślenia, postępowania.

${ }^{11}$ Por. D. Ziółkowski, Z zagadnień dojrzałej religijności, Znak 210 (1971)12, s. 1593; Z. Chlewiński, Religijność dojrzała (Szkic psychologiczny), w: Wybrane zagadnienia z psychologii pastoralnej, red. Z. Chlewiński, Lublin 1989, s. 9-39; tenże, Dojrzałość, osobowość, sumienie, religijność, Poznań 1991, s. 89-92, 104-114. 
samych, w sposób angażujący całą osobę, a nie tylko ze względu na ich znaczenie psychoterapeutyczne czy adaptacyjne ${ }^{12}$. Kolejna cecha dojrzałej religijności - autentyczność - dotyczy sfery religijnych przekonan i może być osiagnięta wtedy, gdy te przekonania zostaną świadomie i dobrowolnie uznane za logiczne i/lub wartościowe ${ }^{13}$.

Dynamika przemian religijności młodzieży wynika z intensywnego i indywidualnie zróżnicowanego rozwoju w okresie dorastania. Szczególnie chodzi tu o jakościowe zmiany funkcji poznawczych (sposobu myślenia) i kształtowanie się osobowości. Te zmiany sprawiają, że stosunek młodzieży do religii przybiera różne, często paradoksalnie sprzeczne formy, co wzmożone jest też chwiejnością emocjonalną charakterystyczną dla wieku dorastania. Młodzież skłonna jest z jednej strony do entuzjazmu i angażowania się we własne lub wspólnotowe życie religijne, a $z$ drugiej strony potrafi szybko się zniechęcić i z błahego powodu odejść od wiary ${ }^{14}$.

$\mathrm{W}$ trakcie swego religijnego rozwoju młodzież często przeżywa tzw. kryzysy religijne $^{15}$. Można je rozumieć jako „przykry stan poznawczo-emocjonalny związany z szeroko pojmowanymi problemami natury religijnej oraz z mniejszą lub większą dezintegracją dotychczasowego życia religijnego osoby go przeżywającej"16.

$\mathrm{Na}$ czym dokładnie polegają kryzysy religijne młodzieży? Przemiany religijności dorastających osób w pewnym momencie mogą osiagnąć krytyczny, przełomowy stopień nasilenia i wywołać wówczas takie wątpliwości religijne, których osoba, stosując dotychczasowe mechanizmy obronne, czy inne wypróbowane sposoby reagowania, nie jest w stanie szybko i skutecznie rozwiązać. Obserwuje się wtedy również „wewnętrzną walkę motywów”. Angażuje ona całą osobowość (intelekt i emocje) i sprawia, że w tej osobowości ujawniają się dwie rywalizujące ze sobą tendencje, stanowiska: „za” i „przeciw” (gdy są one jednakowo silne, kryzys może się przedłużać). Sytuacja kryzysu religijnego powoduje zwykle, że do sposobu dotychczasowego myślenia, oceniania, postępowania wprowadzane są znaczące zmiany. Aby nie „stać w miejscu”, osoba przeżywająca kryzys podejmuje konkretne działania, na przykład: przestaje wykonywać praktyki religijne, wyraża negatywną ocenę swoich dotychczasowych religijnych poglądów (w dużej mierze uwarunkowanych poglądami rodziców), przestaje identyfikować się ze swoją dotychczasową wspólnotą wyznaniową. To zachowanie w pewnym stopniu pomaga redukować przykry stan napięcia ${ }^{17}$.

${ }^{12}$ Z. Chlewiński, Dojrzałość..., s. 90-92.

${ }^{13}$ Tamże, s. 105-106.

${ }^{14}$ R. Murawski, Etapy rozwoju katechezy, Ateneum Kapłańskie 9 (1978)1, s. 71-72; J. Makselon, Dynamika religijności, w: Psychologia dla teologów, red. J. Makselon, Kraków 1990, s. 292.

${ }^{15}$ E. H. Erikson - autor powszechnie znanej teorii kryzysów (popularyzującej pogląd o normatywności kryzysów w poszczególnych okresach życia); sam termin „kryzys” wiązał z trudnościami, jakie towarzyszą przechodzeniu z niższych stadiów rozwoju na wyższe. Por. E. H. Erikson, Dzieciństwo i społeczeństwo, Poznań 1997, s. 257-287. Uważał, że kryzys jest „,koniecznym, zwrotnym momentem rozstrzygajacym, $w$ którym rozwój musi zwrócić się $w$ jedna lub $w$ drugq stronę". O kierunku tego rozwoju decyduje zarówno podmiot, jak i czynnik społeczny. Tenże, Identity, Youth and Crisis, London 1968, s. 16.

${ }^{16}$ Z. Chlewiński, Dojrzałość..., s. 98.

${ }^{17}$ Tamże, s. 98, 101. 
Podobnie jak inne kryzysy życiowe, także kryzysy religijne różnią się między sobą. Istnieją więc różne podziały kryzysów religijnych, w których uwzględnia się między innymi ich przyczyny, formę, w jakiej się one ujawniają oraz skutki, jakie niosą dla dalszego rozwoju ${ }^{18}$.

Przebieg omawianych kryzysów, z religijnego punktu widzenia, może zmierzać w dwóch kierunkach: pozytywnym (gdy w efekcie rozwiązanego kryzysu człowiek pogłębia swoją religijność) i negatywnym (gdy człowiek, w wyniku kryzysu, ostatecznie zaneguje wartości i przekonania religijne, lub przyjmie wobec nich obojętną postawę charakteryzowaną jako indyferentyzm religijny). Natomiast realistyczne rozwiązanie kryzysu religijnego (czyli nie tylko z religijnego punktu widzenia) ma miejsce nie tylko wtedy, gdy jest on rozwiązany „na korzyść” religii. Realistyczne rozwiązanie kryzysu religijnego oznacza, że decyzja o przyjęciu lub odrzuceniu danej religii jest podejmowana ze względu na własne, świadome argumenty, a nie pod wpływem czynników emocjonalnych: buntu, mechanizmów obronnych, czy też pod wpływem panującej mody ${ }^{19}$.

Można uznać, że kryzysy religijne młodzieży mają znaczenie normatywne dla rozwoju jej religijności (mimo że oprócz skutków pozytywnych, powodują również skutki negatywne, co zostało już powyżej opisane). Trudno ich uniknąć, jeżeli chce się osiagnąć dojrzałość religijną. Są one wręcz konieczne dla dezintegracji niektórych struktur, dla zmiany sposobu myślenia o świecie transcendentnym i o własnych relacjach z tym światem. Aby rzeczywiście do tego prowadziły, muszą być umiejętnie rozwiązywane, nierzadko przy pomocy innych osób.

Na powstawanie, przeżywanie i rozwiązywanie kryzysów religijnych w znacznej mierze wpływa środowisko, w którym dorasta młody człowiek. Temat niniejszego artykułu kieruje naszą uwagę na znaczenie grupy rówieśniczej.

\section{Specyfika kryzysów religijnych w poszczególnych grupach rówieśniczych}

Różne są podziały młodzieżowych grup rówieśniczych ${ }^{20}$. W tym artykule ważnym kryterium ich podziału będzie stosunek do religii, zaangażowanie w rozwój religijny. Zakładamy, że kryzysy religijne przeżywane w poszczególnych grupach rówieśniczych różnią się między sobą. Inaczej bowiem musi przebiegać kryzys przeżywany w grupie religijnej przynależącej do Kościoła, inaczej kryzys religijny, który jest wynikiem destrukcyjnego oddziaływania sekty, a inaczej kryzys religijny powstający w grupach zwanych subkulturami. Aby to zrozumieć, trzeba przyjrzeć się ogólnemu i religijnemu rozwojowi młodzieży w poszczególnych grupach rówieśniczych.

${ }^{18}$ Tamże, s. 99-101; J. Makselon, dz. cyt., s. 299-300.

${ }^{19}$ Z. Chlewiński, Dojrzałość..., s. 102.

${ }^{20}$ Por. B. Misztal, dz. cyt., s. 66, 80; R. Łapińska, M. Żebrowska, Wiek dorastania, w: Psychologia rozwojowa dzieci i młodzieży, red. M. Żebrowska, Warszawa 1986, s. 740-751. 


\section{Ku dojrzałej religijności - grupy religijne Kościoła katolickiego}

Grupy rówieśnicze wyjątkowo zaangażowane w życie religijne swoich członków zwykło się określać grupami, wspólnotami, ruchami religijnymi, bądź wyznaniowymi. Wiele z nich zawiązuje się i funkcjonuje wśród młodzieży. Jest to niewątpliwie wynik soborowej i posoborowej polityki Kościoła (zezwalającej na większy niż przed II Soborem Watykańskim udział świeckich w jego życiu). Oprócz różnych funkcji, typowych dla każdej innej grupy rówieśniczej, pełnią one przede wszystkim funkcję religijną ${ }^{21}$.

Znaczenie młodzieżowych grup religijnych wiąże się z celem ich ewangelizacji i polega na włączeniu członków grupy w rzeczywiste życie Kościoła. Ma być to życie świadome, pełne inicjatywy i odpowiedzialności. Jan Paweł II, w Adhortacji apostolskiej Catechesi tradendae, wzywa młodzież:

w imię Jezusa zaklinam młodych, którzy je [grupy o charakterze religijnym - przyp. autora] tworza, ich moderatorów i kapłanów, poświęcających im najlepszą część swojej posługi: nie dopuśćcie żadną miarą, aby w tych grupach - tak bogatych w wartości młodzieńczej przyjaźni i solidarności, radości i entuzjazmu, refleksji nad sprawami i wydarzeniami z życia - zabrakło poważnego studium nauki chrześcijańskiej. W przeciwnym wypadku groziłoby niebezpieczeństwo - co, jakże bolesne, zbyt często już się zdarzało - że grupy te oszukują i swoich członków, i sam Kościół (CT, nr 47).

Grupy religijne mają więc umożliwiać swoim członkom dyskusję ich różnych życiowych problemów, ale jednocześnie mają ich prowadzić do lepszego zrozumienia i pogłębienia wiedzy religijnej oraz budzić i rozwijać wiarę, która zobowiąże ich do dzielenia się nią i do zgodnego z nią życia.

W efekcie religijność młodych członków grup religijnych rozwija się bardziej dynamicznie niż religijność młodzieży niezaangażowanej w życie wspólnot religijnych. Przynależność do takich wspólnot nie gwarantuje co prawda autentycznej głębokiej wiary, ani nie zapewnia rozwiązania wszelkich życiowych problemów. Każe natomiast spojrzeć na życie z innej perspektywy: religijnej. I to okazuje się bardzo istotne, ponieważ prowadzi do przewartościowania dotychczasowych pragnień, dążeń, do zmiany priorytetów. Można uznać, że środowisko wspólnot religijnych stwarza warunki do „religijnego przebudzenia”, otwarcia się na nowe horyzonty wiary ${ }^{22}$.

Ważną cechą, która pomaga przestrzegać normy moralne i która zarazem odróżnia młodzież przynależącą do grup religijnych od jej rówieśników niezrzeszonych

${ }^{21}$ W Polsce, szczególnie w latach siedemdziesiątych ubiegłego stulecia, nasilił się rozwój grup religijnych. Do najbardziej znanych, do dziś prężnie działających, należą: Ruch Światło Życie (tzw. Oaza), Odnowa w Duchu Świętym, grupy neokatechumenalne, młodzież Taizé. Por. M.T. Glogier, Oazy w Polsce, czyli historia ruchu Światto - Życie, Słowo Prawdy 9 (1981), s. 7-13. Por. A. Petrowa-Wasilewicz, Leksykon ruchów i stowarzyszeń w Kościele, Warszawa 2002. Mają one charakter modlitewny, charyzmatyczny, charytatywny, bądź dyskusyjny. Od tego charakteru uzależniają swoje formy działalności. Choć wspólnoty te nie gromadzą tylko i wyłącznie młodzieży, nietrudno zauważyć, że przede wszystkim jej uczestnictwem się cieszą.

${ }^{22}$ J. Bagrowicz, dz. cyt., s. 93. 
w takich grupach, jest głębsza znajomość prawd wiary i bogatsza wiedza religijna ${ }^{23}$. One to, wspólnie z nową hierarchią wartości uświadamiają i przekonują „,wspólnotową" młodzież do podjęcia zobowiązań, które wynikają z bycia człowiekiem wierzącym. Zmniejszają też zagrożenie przeżywania intelektualnych, bądź naukowych wątpliwości religijnych. Dlatego nikłe jest w tych grupach ryzyko wystąpienia kryzysów religijnych na tym tle.

Łatwo tu natomiast o kryzysy spowodowane konfliktem między znanymi dogłębnie (uwarunkowanymi religijnie) zasadami moralnymi, a postępowaniem człowieka. Zdarza się, że młody człowiek zaczyna negować sens tych zasad, bo nie potrafi ich bezwzględnie przestrzegać. Jego skłonność do radykalizmu, wyraźnie wpisana w naturę okresu dorastania, sprawia, że nie może pogodzić się z własną słabością. To zaś paradoksalnie, na zasadzie mechanizmu obronnego, może kształtować u niego bierną, obojętną postawę moralną, która ma łagodzić przykre odczucia związane z przeżywaną duchową rozterką.

Jeśli jednak młody człowiek w takiej sytuacji nie opuści swojej religijnej wspólnoty, ma szansę zrozumieć, że jego słabość nie wyklucza, a jest wręcz potrzebna do osiągnięcia dojrzałości religijnej.

\section{Ku „pseudo-religijności” - sekty}

Sekty ${ }^{24}$ są niewątpliwie typem grup religijnych. Tym jednak, co odróżnia je od grup opisywanych powyżej, może być ich szkodliwy, destrukcyjny psychicznie i społecznie charakter ${ }^{25}$. Na oddziaływanie sekt szczególnie narażona jest młodzież z rodzin wychowawczo-dysfunkcyjnych, odrzucona przez grupę rówieśnicza, bezrobotna ${ }^{26}$.

${ }^{23}$ Co nie jest wcale taką oczywistą sprawą u młodzieży, która nie należy do żadnych wspólnot religijnych. Por. J. Mariański, Postawy młodzieży szkolnej wobec spraw ostatecznych, w: Kościót. Socjologia. Statystyka, red. L. Adamczuk, E. Firlit, A. Ochocki, T. Zembrzuski, Warszawa 1999, s. 136-150; por. P. Brańka, Religijność a percepcja Jana Pawła II przez młodzież, Sosnowiec 2002, s. 55-58.

${ }^{24}$ Spośród wielu definicji sekt przyjmujemy, za Dominikańskim Ośrodkiem Informacji o Nowych Ruchach Religijnych i Sektach, że ,sekta jest instytucją totalną podporządkowaną przywódcy i głoszonej ideologii. Obiecuje realizację uproszczonych celów w uproszczony sposób, odcina się od reszty społeczeństwa, wytwarzając ostre i nie dające się przezwyciężyć podziały na to co 'święte', wewnątrz grupy i 'diabelskie', 'złe' poza grupa.. Manipuluje i wikła uczestników w silną zależność, co może prowadzić do utraty przez nich samodzielności w dysponowaniu własną osobą, osobistym majątkiem i stanowi realne zagrożenie dla ich zdrowia. Przywódcy sekty mogą uważać się za istoty boskie i podejmować za uczestników ważne decyzje życiowe”. Por. Z. Pawłowicz, Kościół i sekty w Polsce, Gdańsk 1992; Niektóre wyznania religijne w Polsce, w: Rocznik Statystyczny Rzeczypospolitej Polskiej GUS, Warszawa 2004; http://sekty.sluzew.dominikanie.pl/czytelnia.html (data dostępu: 17.02.06)

${ }^{25}$ Inne różnice między Kościołem a sektą podaje B. Żerdek. Por. tenże, Sekty i nowe ruchy religijne, Wrocław 1998, s. 21-31; por. także Raport MSWiA, K. Wiktor, G. Mikrut, 15 maja 2000, opublikowany na stronie internetowej http://sekty.sluzew.dominikanie.pl/czytelnia.html (data dostępu: 17.02.06)

${ }^{26}$ Por. Sekty albo nowe ruchy religijne. Wyzwanie duszpasterskie, L'Osservatore Romano 5 (1986), s. $3-6$. 
Wpływ sekt prowadzi najczęściej do destrukcji osobowości członków ${ }^{27}$. Ich osobowość zazwyczaj nie jest jeszcze ukształtowana. Znaczna część członków sekt znajduje się bowiem w okresie dorastania, czyli intensywnego kształtowania, poszukiwania własnej tożsamości. Sekty wykorzystują rodzące się wówczas u młodego człowieka i nasilające się potrzeby: kontaktu, akceptacji, uniezależnienia się od rodziny, a przede wszystkim potrzeby duchowe, które nie zostały zaspokojone w Kościele, jakiego młody człowiek dotychczas doświadczył. Stosując metody i techniki o charakterze manipulacyjnym (psychologiczne, parapsychologiczne, socjologiczne, farmakologiczne $)^{28}$, ukierunkowują ten proces zaspokajania potrzeb i duchowych poszukiwań tak, aby osiagnąć własne, z reguły ukryte cele.

Czy można mówić o rozwoju religijności w sektach? Skoro wiąże się on z rozwojem osobowości, a ta w sektach podległa ciagłej manipulacji, ulega wręcz wypaczeniu, nie sposób twierdzić, aby możliwy był rozwój religijności autonomicznej i autentycznej. Przyjrzyjmy się temu bliżej.

W prawidłowo postępującym rozwoju religijność powinna zmierzać do osiagnięcia autonomii w zakresie motywacji religijnej. Osoba uwikłana w sektę nie zdaje sobie jednak sprawy z przyczyn, dla których przyjmuje głoszone w sekcie prawdy. Wiąże się z tym często problem ukształtowanego w sekcie obrazu Boga. W sytuacji, gdy osoba powinna odchodzić stopniowo od dziecięcej antropomorfizacji i magicznego myślenia o Bogu oraz odrzucać Jego zafałszowaną (najczęściej w wyniku niewłaściwej rodzinnej formacji) wizję, sekty albo podtrzymują takie uproszczone i zniekształcone rozumienie, albo proponują rozumienie inne, dalekie od dojrzałego. Dowodem tego jest motywacja religijności, jaka kształtuje się u wierzących. Ma ona bowiem charakter głównie instrumentalny (wykonywanie praktyk religijnych, oddawanie czci Bogu motywowane jest jedynie strachem, chęcią uzyskania określonych korzyści, lub też zapewnienia sobie odpowiedniej pozycji i opinii). Ważna staje się po prostu chęć przypodobania przywódcy, czy innym członkom sekty (gwarantująca akceptację), bądź najzwyczajniej strach przed odrzuceniem, karą za wyrażanie wątpliwości.

Następną cechą dojrzałej religijności jest jej autentyczność. Trudno zauważyć, aby członkowie sekt posiadali pełną świadomość, zarówno w zakresie przyjmowanych i głoszonych później treści, jak i w zakresie znajomości celów sekciarskiego przekazu (które są ukrywane i realizowane przez ich przywódców). Jeszcze trudniej stwierdzić dobrowolność przyjęcia proponowanej doktryny przez członków sekt (choć oni sami tę dobrowolność, szczególnie na początku, uznają; dopiero osoby, które zamierzają opuścić sektę przekonują się, że ich dobrowolność była pozorna, że była wynikiem manipulacji).

Zaniedbując niektóre podstawowe i wyższe potrzeby człowieka, zastępując je (pozornie) zaspokajaniem potrzeb akceptacji, przynależności, rozwoju religijnego, sekty

${ }^{27}$ Por. Raport MSWiA, dz. cyt.

${ }^{28}$ Te metody i techniki budzą kontrowersje, co do ich zgodności z obowiązującym prawem i z zasadami tolerancji w zakresie wolności sumienia, religii, światopoglądu i zrzeszania. Por. A. Zwoliński, Sekty... Dlaczego?, Warszawa 1998, s. 125-137. 
manipulują swoimi członkami. Opierają się poza tym na instrumentalnej motywacji religijnej swoich członków i nie liczą się z ludzkim prawem wolnego wyboru. Dlatego uważam, że nie powinno się mówić w tym przypadku o kształtowaniu religijności w sektach. Należy raczej mówić o kształtowaniu pseudo-religijności. Religijność bowiem, która nie ma szansy osiagnąć dojrzałej formy (a takiej szansy i odpowiednich warunków nie stwarza właśnie środowisko sekt) nie jest po prostu religijnością.

Jeśli sekta byłaby pierwszym środowiskiem, które mobilizuje osobę do myślenia o Bogu i sprawach związanych z religią, a przy tym nie wpływałaby negatywnie na ogólny rozwój osobowości, można by uznać, że jest w stanie przysłużyć się rozwojowi religijnemu. Niestety, wiadomo, że tak nie jest. Choć sekta niejako inspiruje do podjęcia religijnych poszukiwań, posługuje się zbyt kontrowersyjnymi metodami, aby te poszukiwania uczynić dla siebie korzystnymi. Można co prawda przyjąć, że jeśli dana osoba nie zostanie dalece uwikłana w sektę, to jej pobyt w takiej grupie mimo wszystko ma szansę skończyć się pozytywnie: podjęciem dalszych poszukiwań w sferze religijnej. Z takiego założenia wychodzą niewątpliwie różne ośrodki pomocy osobom uwikłanym w sekty. Jak rzeczywiście wygląda dalszy rozwój religijny tych osób, nie jest już jednak przedmiotem zainteresowań w tym artykule.

Specyfika kryzysów religijnych u członków sekt polegać może w najlepszym przypadku na niejakim „zawieszeniu” rozwoju religijności w ogóle, w najgorszym zaś na znacznym wypaczeniu dotychczasowego sposobu postrzegania i przeżywania wiary, na rozwoju nieautentycznej i nieautonomicznej pseudo-religijności.

Pozytywne rozwiązanie religijnych ,potyczek” dla obecnych i byłych członków sekt nie jest więc łatwe. Sam fakt, że uwikłali się oni w sektę świadczy o tym, że kryzysy religijne przeżywali oni jeszcze „na wolności” i to właśnie te kryzysy stały się główną przyczyną wejścia do sekty. Sekta zaś, wykorzystując je i bazując na nich, pogłębia je i wzmaga, prowadząc niekiedy nawet do zaburzeń psychicznych ${ }^{29}$. Zagrażając ogólnemu rozwojowi osobowości swoich członków, uniemożliwia im rozwój prawdziwej religijności, wymagającej poszanowania ludzkiej wolności i godności.

\section{Grupy neutralne dla rozwoju religijnego młodzieży}

Takie młodzieżowe grupy rówieśnicze, których życie koncentruje się na wielu różnych, ale nie stricte religijnych, sprawach (a przedmiot działania grupowego nie jest sprzeczny z chrześcijańskim światopoglądem - choć niekoniecznie ten światopogląd wprost wyraża) i które nie zajmują całego wolnego czasu swoich członków (dzięki czemu nie niwelują oddziaływań innych grup społecznych), nie zagrażając jednocześnie ogólnemu rozwojowi osobowości, można z pewnością uznać za neutralne dla rozwoju religijnego.

Należy do nich znaczna część tzw. grup spontanicznych i formalnych stowarzyszeń, organizacji młodzieżowych, opierających się na wspólnocie zainteresowań,

${ }^{29}$ A. Zwoliński, Sekty..., s. 149. 
dążeń (czyli na rozwijaniu określonego hobby, działalności charytatywnej itp.). Czegokolwiek by w nich nie czyniono, to nie krytykuje się w nich, ani tym bardziej nie ośmiesza, chrześcijańskich prawd wiary, zasad moralnych i wzorów zachowań. Funkcje tego typu grup odpowiadają funkcjom grup rówieśniczych opisanym na początku niniejszego artykułu.

Niezależnie, czy członkowie grup neutralnych dla ich rozwoju religijnego przebywają w tych grupach, czy nie, ich religijność ma realną szansę zmierzać ku dojrzałości. Przede wszystkim dlatego, że nie wykluczają one wpływu innych grup społecznych i wspomagają prawidłowy rozwój osobowości.

\section{Grupy hamujące rozwój religijności młodzieży}

Jeśli chrześcijańskie prawdy wiary, zasady moralne i wzory zachowań, są przez grupę krytykowane, to jej wpływ na rozwój religijny członków będzie niewątpliwie negatywny. Trudno bowiem o pomyślny przebieg tego rozwoju, jeśli nie jest on wsparty, a wręcz wyklucza korzystne oddziaływanie środowiska społecznego (początkowo rodziny, a później też grupy rówieśniczej).

Wiele spontanicznych rówieśniczych grup młodzieżowych oddala się od wiary i od Kościoła, wiodąc życie podporządkowane współczesnym tendencjom kulturowo-społecznym (postmodernistycznym, sekularyzacyjnym, indywidualizacyjnym), oparte na światopoglądzie podporządkowanym kulturze konsumpcji. Nie sposób opisać dokładnie wpływu tych grup na rozwój religijny swoich członków. Można jedynie przypuszczać, że imponujący im laicki - dalece różny od religijnego, styl życia, odsuwa sprawy religii na margines codziennego życia, przez co hamuje rozwój religijności członków grupy. I przede wszystkim na tym zaniedbaniu polegają przeżywane wówczas (raczej nieświadomie) kryzysy religijne. Niektórzy młodzi ludzie, członkowie opisywanych tu spontanicznych grup rówieśniczych, odwracają się od prawd religijno - moralnych, bo nie chcą podjąć zobowiązań, które z nich wynikają (między innymi w sferze seksualnej). Resztki religijności, jakie usiłują wówczas zachować, składają się na powierzchowne, nierzadko interesowne (motywowane nadzieją na „wymodlenie" sobie czegoś, czy powodowane strachem), emocjonalne relacje z Bogiem (w którego istnienie, bądź pomoc i tak się nie dowierza). Kryzys religijny przeżywany przez takie osoby może prowadzić do kształtowania i utrzymywania się religijności selektywnej lub do religijnego indyferentyzmu. Można go niekiedy określić jako kryzys o charakterze etycznym (szczególnie gdy wzmocniony jest różnymi ,pretensjami do Boga", na przykład o występowanie zła, cierpienia, śmierci itp.).

Jednak na skutek rozwoju osobowości, życiowych doświadczeń, czy też na skutek zetknięcia się z innymi osobami, grupami społecznymi, młodzież przeżywająca tego typu kryzysy religijne, może je łatwo pokonać, a następnie wykorzystać - uznając je za ważny element swojej życiowej drogi do osiagnięcia religijnej dojrzałości.

Spontaniczne grupy rówieśnicze przyjmują niekiedy wartości i postawy, które nie są akceptowane zarówno przez Kościół, jak i przez społeczeństwo. Nazywa się 
je wówczas subkulturami ${ }^{30}$. Jeśli subkulturowa odrębność grup polega na otwartym, głośnym kwestionowaniu i niszczeniu zastanego porządku, wartości i norm społecznych, można uznać te grupy za subkultury dewiacyjne ${ }^{31}$. Niekiedy charakter i działalność subkultur dewiacyjnych wymierzone są i uderzają wprost w wartości chrześcijańskie. Do takich grup zaliczyć można subkulturę satanistów. Jej wpływ na rozwój religijny swoich młodych członków zostanie rozważony poniżej. Nie uczyniono tego wcześniej (przy okazji rozważań na temat sekt) przede wszystkim dlatego, że wśród młodzieży polskiej dominuje tzw. satanizm podwórkowy ${ }^{32}$, a nie intelektualny (intelektualny bowiem wykorzystuje, w radykalny sposób, metody manipulacyjne, aby zatrzymać przy sobie swoich wyznawców; z tego powodu, bardziej niż satanizm podwórkowy, zasługuje on na miano sekty).

Satanizm podwórkowy wynika z ubogiej wiedzy (na temat ideologii i historii satanizmu) oraz z funkcjonowania na granicy prawa lub w niezgodzie z prawem (dewastacje cmentarzy, profanacje nagrobków, znęcanie się nad zwierzętami itp. $)^{33}$. Niektóre elementy satanizmu znajduje się też w subkulturze metalowców ${ }^{34}$. Dla rozwoju tożsamości satanistycznej istotne jest przyjęcie popularnych wierzeń, symboli i obrzędów satanistycznych. Te zaś stanowią antytezę chrześcijaństwa ${ }^{35}$, której wspólnym mianownikiem jest odrzucenie tzw. zdrowego rozsądku, poddanie się emocjom i głębokie zniekształcenie postawy moralnej człowieka (czego przejawem są zboczenia seksualne, żądza władzy, niepohamowana pogoń za pieniądzem i sukcesem, skrajny narcyzm). Wszystkie te elementy oddalają człowieka od Boga i bliźniego. Negują też sens istnienia i poszukiwania prawdziwego, osobistego i wspólnego dobra. Przynależność do subkultury satanistów jest więc akceptacją całkowitego odwrócenia wartości. To, co dla większości społeczeństwa jest obiektywnie złe, błędne i moralnie nieuporządkowane, dla satanistów okazuje się atrakcyjne, wzorowe. Chcą oni przecież wyzwolić się z krępujących norm społecznych, zwłaszcza religijnych. Powszechna w ich

${ }^{30}$ Pojęciu temu nie należy jednak przypisywać tylko negatywnego znaczenia. Życie w subkulturach opiera się wprawdzie na wartościach i normach postępowania, których nie uznaje kultura dominująca, nie zawsze jednak prowadzi to do otwartej walki z tymi „społecznymi” wartościami. Istnienie subkultur może być bowiem naturalnym wynikiem dorastania we współczesnej kulturze lub/i również wyrazem buntu przeciw wszystkiemu, co jest dziełem ludzi dorosłych.

${ }^{31}$ Definicji subkultur, a raczej ich propozycji, jest mnóstwo. Zamiennie, albo dopełniająco stosuje się jeszcze takie określenia, jak: podkultura, kultura alternatywna, kultura młodzieżowa. Por. A. Kłoskowska, Socjologia kultury, Warszawa 1981, s. 547; J. Wertenstein - Żuławski, To tylko rock'n'roll, Warszawa 1990, s. 10; M. Pęczak, Mały Słownik Subkultur Młodzieżowych, Warszawa 1992, s. 4; B. Fatyga, Dzicy z naszej ulicy. Antropologia kultury młodzieżowej, Warszawa 1999, s. 107-108; M. Filipiak, Od subkultury do kultury alternatywnej, Lublin 1999, s. 13-17, 95-98;

P. Piotrowski, Subkultury młodzieżowe. Aspekty psychologiczne, Warszawa 2003, s. 12-14.

${ }^{32} \mathrm{http}: / /$ www3.uj.edu.pl/Relig/Prac/listanrr/satanizm.htm (data dostępu:17.02.06).

${ }^{33}$ Tamże.

${ }^{34}$ P. Piotrowski, Subkultury młodzieżowe. Aspekty psychospołeczne, Warszawa 2003, s. 84-85.

${ }^{35}$ Por. M. Jędrzejewski, Młodzież a subkultury, Warszawa 1999, s. 112-118; P. Piotrowski, dz. cyt., s. 75-78. 
środowisku zasada „Czyń, co chcesz, a tylko to będzie prawem” przekonuje, że wolność człowieka wcale nie kończy się tam, gdzie zaczyna się wolność innych ${ }^{36}$.

Trudno mówić o jakimkolwiek rozwoju religijnym członków takiej subkultury. Jest on całkowicie zahamowany. To zaś, co rozwija się w duchowości satanistów jest po prostu skłonnością do czynienia zła, a nie dobra. Duchowe otwarcie, które się dokonuje w satanistach nie jest otwarciem na bliźniego, albo na Boga, ale przeciwnie: na siebie samego (własne potrzeby, dążenia) i na działanie szatana. Przebywanie w subkulturach satanistycznych związane jest więc nie tylko z upowszechnianiem zachowań dewiacyjnych, ale również z religijną regresją.

Inne subkultury, które hamują rozwój religijny swoich członków (już nie tak drastyczne, skrajne w swych działaniach, jak sataniści) to na przykład skinheadzi (preferujący kult siły i przemocy, nacjonalizm, nienawiść i pogardę dla ludzi słabszych) ${ }^{37}$ i anarchiści (głoszący bezwzględną wolność każdego człowieka, łamanie wszelkich zasad, trzymanie się własnej moralności i wypowiadający wojnę wszelkim instytucjom, szczególnie państwu i Kościołowi) ${ }^{38}$.

Kryzysy religijne członków subkultur młodzieżowych polegają najczęściej na odejściu od Kościoła, a nawet na walce z Kościołem. Jednak, w przeciwieństwie do sekt, członkowie tych subkultur, w większości „wyrastają" z grupowego konformizmu. Wówczas to mają szczególną szansę pozytywnie rozwiązać swój religijny kryzys, co jednak nie zawsze wykorzystują (zależy to również od innych czynników, na przykład od wpływu innych grup społecznych).

\section{Podsumowanie}

Duża ilość czasu, jaką młodzież poświęca na przebywanie w grupie rówieśniczej, podobieństwa zainteresowań członków grupy, pogłębiające i utrwalające się więzi emocjonalne, bogactwo wspólnych przeżyć, doświadczeń - wszystkie te elementy decydują o wzrastającym wpływie grupy na różne sfery życia młodzieży, w tym na jej życie religijne. Oddziaływania grup rówieśniczych mogą zarówno wzmocnić, jak i osłabić intensywność i głębię przeżywania religijności (osłabić zwłaszcza wtedy, gdy charakter grupy jest sprzeczny z chrześcijańskim światopoglądem). Mogą spowodować, że członkowie danej grupy zaniedbają dotychczas czynione praktyki religijne, a w konsekwencji zerwą więzi ze wspólnotami kościelnymi.

Grupy rówieśnicze mogą też nie spełniać żadnej istotnej, konkretnej roli - nie stymulując, ani nie hamując rozwoju religijnego. Wszystko zależy od tego, czy należą do nich osoby o przychylnym, obojętnym, czy negatywnym nastawieniu wobec religii, oraz od wartości, jakie te osoby cenią i uważają za priorytetowe. Jeśli są to

${ }^{36} \mathrm{http}: / /$ www.apologetyka.katolik.pl/polemiki/satanizm/loservatoreromano/index.ph (data dostępu: 17.02.06).

${ }^{37} \mathrm{http} / / /$ sweb.cz/skinheadns/pl; http://skinhead.w.interia.pl (data dostępu: 17.02.06)

${ }^{38}$ Por. M. Jędrzejewski, dz. cyt., s. 136-140; http://www.powitanie.com.pl/ami/8/8sub.htm (data dostępu: 17.02.06) 
chrześcijańskie wartości i normy oraz wzory zachowań na nich oparte, to grupa rówieśników może się okazać najlepszą, bądź nawet pierwszą szkołą inicjacji chrześcijańskiej (szczególnie, gdy jej młody uczestnik dorasta w rodzinie indyferentnej religijnie bądź w rodzinie ateistycznej).

Ważny jest wpływ innych grup społecznych na młodzież. Mimo że jest on mniejszy (co uwarunkowane jest rozwojowymi prawidłowościami), to jednak wciąż niezbędny. W różnych bowiem momentach swojego życia młodzież może potrzebować uwagi i wsparcia w przezwyciężaniu religijnych wątpliwości, czy kryzysów. I tu znajdujemy zadanie dla pedagogów chrześcijańskich, duszpasterzy, ale także dla rodziców, którym zależy na religijnym rozwoju ich dorastających dzieci. Zadanie to nie dotyczy bynajmniej bezpośredniej ingerencji w życie młodzieżowych grup rówieśniczych. Chodzi raczej o uświadomienie sobie ich znaczenia, a następnie zdobycie informacji, do jakiej grupy należy młody człowiek, z którym mamy kontakt. Aby towarzyszyć mu, wspierać go w religijnym rozwoju, musimy poznać specyfikę środowiska, w którym przebywa, które mu imponuje.

\section{Young peer groups versus religion crisises nowadays (Summary)}

This article discoveres and describes that part of youth groups life which influences the way of religious crisises. Here you can find the answer for question: how particular youth grups influence religious growing (in other words: how they influence appearance and form of religious crisises)? First, you will know or you will bring to your mind the sens of youth grups in adolescence and the rules of religious growing in adolescence. 